Articles and Essays by Gerald C. Wright, Jr., J. Miller McPherson, Susan Welch, and Cal Clark, Thomas C. Nowak, Robert A. Bernstein, Clarke E. Cochran, Michael S. Lewis-Beck, Steven R. Brown, Robert C. Tucker, Sidney I. Ploss, George Breslauer

\title{
Robert Eyestone
}

Confusion, Diffusion, and Innovation

Gerald S. Strom and Barry S. Rundquist

A Revised Theory of Winning in House-Senate Conferences

Edward N. Muller

Behavioral Correlates of Political Support

Shaheen F. Dil

The Cabal in Kabul

Paul Allen Beck

Partisan Dealignment in the Postwar South

Published Quarterly by

The American Political Science Association

Vol. LXXI June $1977 \quad$ No. 2 


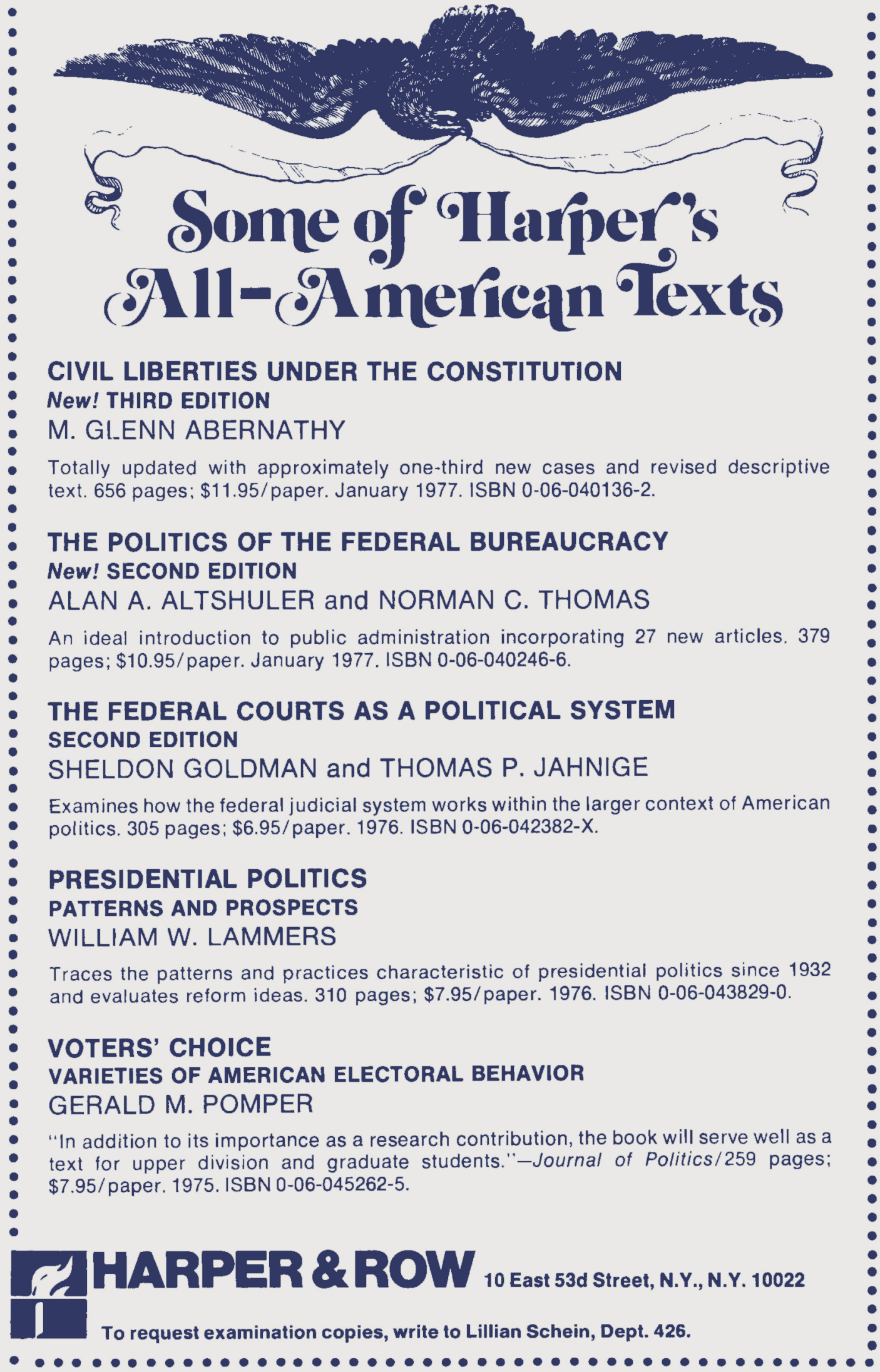




\section{The American Political Science Review}

Vol. LXXI

June 1977

No. 2

\section{CONTENTS}

441 Confusion, Diffusion, and Innovation

Robert Eyestone

448 A Revised Theory of Winning in House-Senate Conferences

Gerald S. Strom and Barry S. Rundquist

454 Behavioral Correlates of Political Support

Edward N. Muller

468 The Cabal in Kabul: Great-Power Interaction in Afghanistan

Shaheen F. Dil

477 Partisan Dealignment in the Postwar South

Paul Allen Beck

497 Contextual Models of Electoral Behavior: The Southern Wallace Vote Gerald C. Wright, Jr.

509 The Stability and Reliability of Political Efficacy: Using Path Analysis to Test
Alternative Models
J. Miller McPherson, Susan Welch, and Cal Clark

522 The Philippines Before Martial Law: A Study in Politics and Administration

Thomas C. Nowak

540 Divisive Primaries Do Hurt: U.S. Senate Races, 1956-1972

Robert A. Bernstein

546 Authority and Community: The Contributions of Carl Friedrich, Yves R. Simon, and Michael Polanyi

Clarke E. Cochran

559 The Relative Importance of Socioeconomic and Political Variables for Public Policy

Michael S. Lewis-Beck

567 Political Literature and the Response of the Reader: Experimental Studies of Interpretation, Imagery, and Criticism

Steven R. Brown

585 Communications

603 Editorial Comment

606 Book Reviews and Essays

606 The Georges' Wilson Reexamined: An Essay on Psychobiography

Robert C. Tucker We Remember Khrushchev

624 Khrushchev Remembers: A Review Essay

Sidney I. Ploss

627 Comment

George Breslauer Rejoinder

Sidney I. Ploss

Office of publication: Curtis Reed Plaza, Menasha, Wisconsin.

Foreign Agent: P. S. King and Staples, Ltd., Great Smith Street, Westminster, London.

Second class postage paid at Washington, D.C., and at additional mailing offices.

Printed in the United States of America by George Banta Company, Inc., Menasha, Wisconsin.

Composition by TypoGraphics, Columbia, Maryland.

Copyright, 1977, by The American Political Science Association 
441 Confusion, Diffusion, and Innovation. The apparent fact that interactive effects are more common in policy innovations taking a long time to diffuse among the states, contrary to the presumed effects of interaction, suggests the existence of alternate diffusion mechanisms. Some policies diffuse directly from a federal model, while others diffuse among states via a segmented pattern of emulations. The order of state adoption of fair employment practices legislation is compared with the adoption order for three labor policies and two civil rights policies. Fair employment practice, by this test, is identified as a civil rights policy and not as a labor policy. State minimum wage legislation is discussed as a case of federal influence in the diffusion process. A first wave of diffusion was followed by a period of federally inspired court rescission. Federal legislation in 1938 began another wave of diffusion. In a third wave of innovations, states with existing laws amended those laws by emulating the new federal legislation.

By ROBERT Eyestone, Associate Professor of Political Science, University of Minnesota.

448 A Revised Theory of Winning in House-Senate Conferences. The question, "Who wins in House-Senate conferences?" has largely been answered for recent Congresses. But the question, "Why does the Senate win?" has not been adequately answered. The research reported here presents and tests some necessary conditions of a theory that provides an answer to this question. The Senate wins because it is most frequently the second acting chamber and, because it has constitutionally derived power over House decisions, giving it the capacity to get the adjustments it makes in House bills accepted in conference. In the minority of cases in which the Senate acts first, the House "wins" in conference. Unlike earlier attempts to explain conference outcomes, the theory proposed here is consistent with the overall pattern of House dominance in the legislative process.

By Gerald S. STROM, Assistant Professor of Political Science, University of Ilinois at Chicago Circle, and BARRY S. RUNDQUIST, Assistant Professor of Political Science, University' of Illinois at Urbana-Champaign.

454 Behavioral Correlates of Political Support. Theories of the behavioral consequences of political support coincide in the prediction that political support will correlate positively with indices of conventional behavior, negatively with indices of unconventional behavior. Survey data drawn from three communities in the Federal Republic of Germany show that an index of support for the structure of political authority is negatively correlated both with an index of actual participation in aggressive political behavior and with an index of participation in conventional electoral/pressure-group politics. Since the political behavior indices are themselves positively correlated, it is useful to construct a typology which differentiates between "pure" types - no participation, participation only in conventional, participation only in aggressive - and "mixed" types - participation in conventional and moderately aggressive, participation in conventional and highly aggressive. When the relationship between political support and the political-action type index is examined, it turns out that two of the types are associated with medium political support, while four of them occur at low support. To achieve more accurate explanation of types of political behavior, a model for prediction of each action type is proposed, taking into account interaction between political support, sense of personal political influence, and belief in the efficacy of past collective political aggression. The test of the model yields positive results, suggesting that it represents a fruitful beginning toward development of a theory of behavioral consequences of political support.

By EDWARD N. MULLER, Associate Professor of Political Science, State University of New York at Stony Brook.

468 The Cabal in Kabul: Great-Power Interaction in Afghanistan. The July 17, 1973 coup serves as a case study of the nature and extent of great-power interest and involvement in Afghanistan. The dynamics of American, Soviet, and Chinese interaction are multifaceted and volatile, and imply that no one great power had outright control. Thus, this treatment concerns influence rather than control, and multilateral interaction rather than unilateral or bilateral action. The differing interests of the great powers in Afghanistan are outlined. Next, the possibility of great-power involvement in the coup is examined. Finally, the impact of the coup upon Afghanistan's relations with the three great powers is considered. Available material suggests that neither the United States nor the People's Republic of China had sufficient interest or influence to instigate the coup. Nor is there any concrete evidence that the Soviet Union played a significant role, although it did have the opportunity, influence, and interests to do so.

By SHAHEEN F. Dil, Assistant Professor of Political Science, Mount Holyoke College.

477 Partisan Dealignment in the Postwar South. This study attempts to explain post-World War II southern electoral politics by examining the party identifications of southerners between 1952 and 1972. Pronounced decreases in Democratic loyalties and increases in Independent leanings appear during this 
period and constitute a dealignment of the southern electorate. While interregional population exchanges have diluted Democratic strength, their effects are almost counterbalanced by the mobilization of blacks into politics. Instead, the principal source of dealignment is the generational replacement of the native white electorate. Its youngest members, who entered the electorate after World War II, have come to favor political independence increasingly in recent years. This behavior seems partially attributable to a tendency for young native whites in particular to bring their partisan loyalties into line with their at titudes and party images on racial issues. Even so, there are clear signs that the racial question is losing its place as the major determinant of the region's politics. For the future, one can expect a continuation of dealignment politics and little chance of a partisan realignment.

By PAUl Allen Beck, Associate Professor of Political Science, University of Pittsburgh.

497 Contextual Models of Electoral Behavior: The Southern Wallace Vote. Many studies have sought to investigate contextual influences on individual electoral behavior using aggregate data. The shortcomings of this approach are discussed, focusing on the relationship between black concentration and southern white support for George Wallace for president in 1968. Through combining aggregate and individual-level data and comparing a series of models, black concentration is found to increase white support for Wallace. Intraregional differences in the relationship between white support for Wallace and local black concentration are equalized when contextual influences at the state level are brought into the analysis. Black concentration contextual effects are independent of those of urbanization, education, or residence in Wallace's home state of Alabama. Relative primary group support for Wallace and relative issue proximity to Wallace are then shown to be the intervening variables linking contextual characteristics and electoral choice.

By Gerald C. WRIGHT, JR., Associate Professor, Florida Atlantic University.

509 The Stability and Reliability of Political Efficacy: Using Path Analysis to Test Alternative Models. The reliability and stability of survey items designed to measure political attitudes are important to the study of political behavior. Several past studies have examined the reliability and stability of items measuring one construct, that of political efficacy. The results of this prior research have been contradictory, in part because of the limitations of the methodologies used. In this article, the authors employ path analysis to examine more closely the stability and reliability of the four SRC items commonly used to measure political efficacy. The American Panel Study (1956-1960), in which efficacy is measured at two points in time, is used as the data base. The authors conclude that two of the four items (NO CARE and NO SAY) seem to measure best what is meant by political efficacy. These two items are more stable and reliable than previously thought, while the other items are relatively unstable and unreliable, and they display systematic differences from each other and from the NO CARE and NO SAY items.

By J. MILleR MCPHERSON, Associate Professor of Sociology, University of Nebraska; SUSAN WELCH, Associate Professor of Political Science, University of Nebraska; and CAL CLARK, Assistant Professor of Political Science, New Mexico State University.

522 The Philippines Before Martial Law: A Study in Politics and Administration. In the period following World War II before the declaration of martial law in the Philippines, politics and heavy demands for patronage affected the allocation of resources, the administrative process, and personnel policies in ways inimical to the interests of businessmen and technocrats. When faced with intense competition, politicians pressed to employ growing numbers of clients and protéges in local administration. Strong political machines were better able than weak machines to ignore pressures for social services benefitting largely the lower class. The level of political mobilization and size of the lower class increased expenditures on primary education, and expenditures on intermediate and secondary education grew as the percentage of the electorate that was lower class increased. To the dismay of business interests and technocrats, "wasteful" expenditures on local administration and social services were most institutionalized and difficult to cut, while expenditures on economic improvements proved more elastic.

By ThOmAS C. NOWAK, Assistant Professor of Sociology and Economics, Indiana University of Pennsylvania.

540 Divisive Primaries Do Hurt: U.S. Senate Races, 1956-1972. This analysis shows, in contrast to previously published work, that a divisive primary hurts a senatorial candidate's chances for success in the general election. The relationship between divisiveness and lack of success continues to hold when incumbency and state party orientations are controlled. This relationship has an important implication regarding representation. The fact that divisive primaries do hurt strengthens the representation of weak and minor state parties in the U.S. Senate.

By Robert A. BERnSTEIN, Associate Professor of Political Science, Texas A \& M University. 
546 Authority and Community: The Contributions of Carl Friedrich, Yves R. Simon, and Michael Polanyi. The problem of authority has a practical and a theoretical side. Practically, the decline of authority contributes to the crisis of legitimacy in contemporary governments and to difficulties in the practice of morality. Theoretically, authority is often confused with power, force, or coercion. Thus, it is viewed with suspicion. The thesis of this paper is that authority is not a form of power; rather, it transforms power. Like power, force, and coercion, authority is directive, but it is so in quite a different way. An examination of the concept of authority in three very different theorists - Carl Friedrich, Yves R. Simon, and Michael Polanyi - reveals that a sound concept of authority must be rooted in community as a system of shared beliefs, experiences, and traditions and in transcendent standards referred to by such beliefs, experiences, and traditions. Authority is that which directs a community to its proper end.

\section{By Clarke E. Cochran, Associate Professor of Political Science, Texas Tech University.}

559 The Relative Importance of Socioeconomic and Political Variables for Public Policy. Since Dawson and Robinson, a dominant issue in the quantitative study of public policy has been the relative importance of socioeconomic and political variables for determining policy outcomes. It is argued here that past efforts to resolve this issue have been unsatisfactory, largely because they relied on inadequate statistical techniques, i.e., simple correlation, partial correlation, or multiple regression. Coefficients from these techniques are irrelevant for all but the most peculiar models of public policy. In general, if the researcher wishes to assess the relative importance of independent variables, it will be necessary to resort to path analysis of a formally constructed causal model. The comparison of "effects coefficients," derived from path analysis, is offered as the preferred means of evaluating independent variables, superior to comparisons of coefficients from simple correlation, partial correlation, or multiple regression. When the effects coefficients are actually calculated for a popular model of welfare policy, socioeconomic variables appear much more important than political variables, contrary to interpretations coming from the more traditional statistical techniques.

By MICHAEL S. LEWIS-BECK, Assistant Professor of Political Science, University of Iowa.

567 Political Literature and the Response of the Reader: Experimental Studies of Interpretation, Imagery, and Criticism. The influence of political literature has often proved elusive to empirical political science, partly because of the subjectivity of literary response, and partly because of social science methods which are largely incapable of dealing with subjective phenomena in a satisfactory way. A distinction is made between the experimental methods of expression which focus on objective responses, and the methods of impression which focus on subjective responses. Experimental methods are then applied to interpretations of Golding's Lord of the Flies, to the effects on imagery of reading Mazlish's In Search of Nixon, and to reactions to Burdick's The Ninth Wave. An illustration is also given of the experimental study of literary response in the single case.

By STEVEN R. BROWN, Professor of Political Science, Kent State University.

\section{COMMUNICATIONS}

From Jeff Stonecash, Vaughn Altemus, Theodore F. Macaluso, Jerrold G. Rusk, George Otte and Ruediger Zuelch, Robert C. Fried, Alexander L. George, Rubin G. Cohn, Byron W. Daynes.

\section{EDITORIAL COMMENT}

\section{BOOK REVIEWS AND ESSAYS}

The Georges' Wilson Reexamined: An Essay on Psychobiography. Psychobiography interprets a life-course in terms of a consciously thought-out interpretation of the subject's personality. There are criteria for judging the relative merit of differing lines of interpretation. The Georges' Woodrow Wilson and Colonel House, rightly recognized as a psychobiographical classic, proceeds from Harold Lasswell's formula for "political man" as one who seeks power to overcome a low selfestimate. The formula is in some respects questionable. The Georges' generally effective application of it falls short of full success. An alternative interpretation, based on the view that Wilson's life exemplified the neurotic search for glory as described by Karen Horney, is explored. The two different lines of interpretation are compared with respect to what Alexander George has called the "self-defeating pattern" in Wilson's career as a leader.

By ROBERT C. TUCKER, Professor of Politics, Princeton University.

619 Khrushchev Remembers: A Review Essay. Strobe Talbott, editor and translator, Khrushchev Remembers; Strobe Talbott, editor and translator, Khrushchev Remembers: The Last Testament.

By SIDNEY I. PLOSS, Washington, D.C. 
624 Comment. By GeORge Breslauer, Assistant Professor of Political Science, University of California, Berkeley.

627 Rejoinder. By SIDNEY I. PLOSS.

629 Political Theory, History of Political Thought and Methodology

Francis Allen, The Crimes of Politics: Political Dimensions of Criminal Justice. Austin Sarat, p. 629.

Stanislav Andreski, ed., The Essential Comte. H. M. Höpfl, p. 630.

David Beetham, Max Weber and the Theory of Modern Politics. Avery Leiserson, p. 631.

Lewis A. Coser, Greedy Institutions: Patterns of Undivided Commitment. Guenther Roth, p. 632.

J. Alvarez del Vayo, The March of Socialism. David McLellan, p. 634.

Michael Fellman, The Unbounded Frame: Freedom and Community in Nineteenth-Century American Utopianism. William J. Meyer, p. 634 .

Morris P. Fiorina, Representatives, Roll Calls, and Constituencies. Herbert B. Asher, p. 635.

Grant Gilmore, The Death of Contract. P. S. Atiyah, p. 636.

G. M. A. Grube, trans., Plato's Republic Thomas L. Pangle, p. 637.

Max Horkheimer, Critique of Instrumental Reason: Lectures and Essays Since the End of World War II. Julius Carlebach, p. 639.

John D. Hutcheson, Jr. and Frank X. Steggert, Organized Citizen Participation in Urban Areas. Allen K. Settle, p. 640.

Russell Kirk, The Roots of American Order. Robert W. Hoffert, p. 640.

Manfred Kochen, Integrative Mechanisms in Literature Growth. Kenneth Janda, p. 642.

Alexandre Kojève, Kant. Patrick Riley, p. 643.

Ralph Lerner, trans., Averroes on Plato's Republic. R. G. Mulgan, p. 645.

Alfred Levin, The Third Duma, Election and Profile. Ben-Cion Pinchuk, p. 646.

Hyman Lumer, ed., Lenin on the Jewish Question. William Kopey, p. 647.

Tomás G. Masaryk, The Meaning of Czech History. Zdenek Krystufek, p. 648.

Ezekiel Mphahlele, The African Image, rev. ed. Edgar S. Efrat, p. 649.

Herbert J. Muller, Uses of the Future. Victor Ferkiss, p. 650.

George Nakhnikian, ed., Bertrand Russell's Philosophy. Joel Kassiola, p. 651.

Frank O' Gorman, Edmund Burke: His Political Philosophy. John A. Gueguen, p. 653

Bhikhu Parekh, ed., Jeremy Bentham: Ten Critical Essays. Wilfrid Harrison, p. 654.

Stanley Allen Renshon, Psychological Needs and Political Behavior: A Theory of Personality and Political Efficacy. Meredith W. Watts, p. 655.

Philip Rosenberg, The Seventh Hero: Thomas Carlyle and the Theory of Radical Activism. Thomas S. Engeman, p. 657.

Steven J. Rosen and James R. Kurth, eds., Testing Theories of Economic Imperialism. Kenneth E. Boulding, p. 658.

Ralph Ross, Herbert W. Schneider, and Theodore Waldman, eds., Thomas Hobbes in His Time. Harvey C. Mansfield, Jr., p. 660.

Jack Rothman, Planning and Organizing for Social Change: Action Principles From Social Science Research. Charles H. Levine, p. 661.

Stephen Schafer, The Political Criminal: The Problem of Morality and Crime. Michael E. Milakovich, p. 662.

Glendon Schubert, The Judicial Mind Revisited: Psychometric Analysis of Supreme Court Ideology. Fred Kort, p. 664 .

Eugene Schulkind, ed., The Paris Commune of 1871: The View from the Left. John Horne, p. 665.

Thomas Smith, De Republica Anglorum: A Discourse on the Commonwealth of England. Ernest L. Fortin, p. 666.

Thomas Sowell, Classical Economics Reconsidered. Mark Blaug, p. 667.

Leo Strauss, The Argument and the Action of Plato's 'Laws.' David Bolotin, p. 668.

Frederic Wakeman, Jr., History and Will: Philosophical Perspectives of ifao Tse-tung's Thought. Stuart R. Schram, p. 670 .

W. F. Wertheim, Evolution and Revolution: The Rising Waves of Emancipation. Walter C. Opello, Jr., p. 672.

Robert A. Wicklund, Freedom and Reactance. Peter G. Stillman, p. 673.

Edward O. Wilson, Sociobiology: The New Synthesis. Roger D. Masters, p. 674.

Gerhard Wurzbacher, ed., Sozialisation und Personalisation: Beiträge zu Begriff und Theorie der Sozialisation. Glenn N. Schram, p. 676.

677 American Government and Politics

Douglas Adair, Fame and the Founding Fathers: Essays by Douglas Adair, Larry Peterman, p. 677.

Corbin Allardice and Edward R. Trapnell, The Atomic Emergy Commission. Joan E. Spero, p. 678. 
Philip G. Altbach, Student Politics in America: A Historical Analysis. Norman C. Thomas, p. 679.

Edward J. Bacciocco, Jr., The New Left in America: Reform to Revolution 1956-1970. Dale Vree, p. 680.

John F. and Rosemary S. Bannon, Law,Morality and Vietnam: The Peace Militants and the Courts. Michael E. Smith, p. 681 .

James David Barber, ed., Choosing the President. Sidney Wise, p. 682.

Sotirios A. Barber, The Constitution and the Delegation of Congressional Power. C. Herman Pritchett, p. 683.

William D. Barnard, Dixiecrats and Democrats: Alabama Politics 1942-1950. William H. Stewart, Jr., p. 684.

Alan Barth, Prophets With Honor: Great Dissenters in the Supreme Court. Richard E. Morgan, p. 685.

Beatrice B. Berle and Travis B. Jacobs, eds., Navigating the Rapids 1918-1971: From the Papers of Adolf A. Berle; Thomas M. Campbell and George C. Herring, eds., The Diaries of Edward R. Stettinius, Jr.. 1943-1946; Senator J. William Fulbright, The Crippled Giant: American Foreign Policy and Its Domestic Consequences; Michael A. Guhin, John Foster Dulles: A Statesman and His Times; Henry Cabot Lodge, The Storm Has Many Eyes: A Personal Narrative. S. Shepard Jones, p. 686.

Frederick J. Blue, The Free Soilers: Third Party Politics, 1848-54. Donald Allen Robinson, p. 690.

James Bolner and Robert Shanley, Busing: The Political and Judicial Process. Howard Sherain, p. 691.

Michael J. Brenner, The Political Economy of America's Environmental Dilemma. Harvey Lieber, p. 692. Robert Burkhardt, The Civil Aeronautics Board. William E. O'Connor, p. 692.

David A. Caputo and Richard L. Cole, Urban Politics and Decentralization: The Case of General Revenue Sharing. Michael D. Reagan, p. 693.

Lois Green Carr and David William Jordan, Maryland's Revolution of Government 1689-1692. Peter S. Onuf, p. 694.

Anthony James Catanese, Planners and Local Politics: Impossible Dreams. John J. Harrigan, p. 695.

O. Edmund Clubb, The Witness and I. Joseph W. Escherick, p. 696.

Bernard C. Cohen, The Public's Impact on Foreign Policy. Leon V. Sigal, p. 697.

Richard L. Cole, Citizen Participation and the Urban Policy Process; Stanley B. Greenberg, Politics and Poverty: Modernization and Response in Five Poor Neighborhoods. John Mollenkopf, p. 698.

Robert H. Connery and Gerald Benjamin, eds., Governing New York State: The Rockefeller Years. Stephen M. David, p. 700.

Richard F. Fenno, Jr., Congressmen in Committees. David E. Price, p. 701.

Joyce D. Fishbane and Glen W. Fisher, Politics of the Purse: Revenue and Finance in the Sixth Mlinois Constitutional Convention. James P. Pfiffner, p. 704.

Patrick J. Gallo, Ethnic Alienation: The Italian-Americans. Norma De Candido, p. 705.

Lewis G. Gould, ed., The Progressive Era. David W. Marcell, p. 706.

Ernesi S. Griffith, $A$ History of American City Government, 2 vols. Joseph F. Freeman, p. 707.

Charles Hampden-Turner, From Poverty to Dignity: A Strategy for Poor Americans. Theodore J. Lowi, p. 708.

Willis D. Hawley, Nonpartisan Elections and the Case for Party Politics. Frank J. Sorauf, p. 709.

John Helmer, Bringing Home the War: The American Soldier in Vietnam and After. William J. Crotty, p. 710 .

Harold Hochman and George Peterson, eds., Redistribution Through Public Choice. William Niskanen, p. 711.

John C. Hogan, The Schools, the Courts, and the Public Interest. David Fellman, p. 712.

A. E. Dick Howard, Commentaries on the Constitution of Virginia, 2 vols. Albert L. Sturm, p. 714.

Stephen D. Isaacs, Jews and American Politics. Stanley Rothman, p. 715.

Larry R. Jackson and William A. Johnson, Protest by the Poor: The Welfare Rights Movement in New York City. Michael V. Gershowitz, p. 716.

M. Kent Jennings and Richard G. Niemi, The Political Character of Adolescence: The Influence of Families and Schools. Judith V. Torney, p. 717.

Edward R. Kantowicz, Polish-American Politics in Chicago. Andrew M. Greeley, p. 719.

Walter Karp, Indispensable Enemies: The Politics of Misrule in America. Hugh A. Bone, p. 720.

George R. LaNoue and Bruce L. R. Smith, The Politics of School Decentralization. Jeffrey A. Raffel, p. 721.

David Mechanic, Politics, Medicine and Social Science. Oliver Garceau, p. 722.

August Meier and Elliot Rudwick, CORE: A Study in the Civil Rights Movement, 1942-1968. Michael Lipsky, p. 723.

D. Stark Murray, Blueprint for Health: A Multinational Portrait of the Costs and Administration of Medical Care in the Public Interest. John H. Romani, p. 725.

David W. Neubauer, Criminal Justice in Middle America. Suzanne R. Weaver, p. 726.

Arthur M. Okun, Equality and Efficiency: The Big Tradeoff. Aaron Wildavsky, p. 727.

Joseph B. Parker, The Morrison Era: Reform Politics in New Orleans. William C. Havard, p. 728.

Austin Ranney, Curing the Mischiefs of Faction: Party Reform in America. Milton C. Cummings, Jr., p. 729.

Steven E. Rhoads, Policy Analysis in the Federal Aviation Administration. Allen Schick, p. 731. 
Richard Rose, ed., Lessons from America: An Exploration. Karl M. Schmidt, p. 732.

James N. Rosenau, Citizenship Between Elections: An Inquiry Into the Mobilizable American. Donald J. Devine, p. 733.

Warren Rovetch and John J. Gaskie, Program Budgeting for Planners: A Case Study of Appalachia with Projections Through 1985. James E. Skok, p. 735.

Ralph Sanders, The Politics of Defense Analysis. Harold L. Hitchens, p. 736.

Charles Sheldon, The American Judicial Process: Models and Approaches. S. Sidney Ulmer, p. 737.

Robert G. Wirsig, ed., International Relations and the Future of Ocean Space, E. D. Brown, p. 738.

Alan L. Sorkin, Education, Unemployment, and Economic Growth. Farhat Ghaem Maghami, p. 739.

John G. Stewart, One Last Chance: The Democratic Party, 1974-76. Edward Schneier, p. 740.

John Staples Shockley, Chicano Revolt in a Texas Town. Irving O. Dawson, p. 741.

Otto G. Stolze, Revenue Sharing: Legal and Policy Analysis. William H. Young, p. 742.

Bert Strauss and Mary E. Stowe, How to Get Things Changed: A Handbook for Tackling Community Problems. Shirley E. Ostholm, p. 743.

Philippa Strum, The Supreme Court and "Political Questions": A Study in Judicial Evasion. Lois B. Moreland, p. 744.

Denis G. Sullivan, Jeffrey L. Pressman, Benjamin I. Page, and John J. Lyons, The Politics of Representation: The Democratic Convention of 1972. Clarence A. Berdahl, p. 745.

George M. von Furstenberg, Bennett Harrison, and Ann R. Horowitz, eds., Patterns of Racial Discrimination, 2 vols.; Arthur P. Solomon, Housing the Urban Poor: A Critical Evaluation of Federal Housing Policy. Judith V. May, p. 746.

Michael J. White, Management Science in Federal Agencies. Raymond Pomerleau, p. 748.

Paul B. Wice, Freedom for Sale: A National Study of Pretrial Release. Neal A. Milner, p. 749.

Allen Yarnell, Democrats and Progressives: The 1948 Presidential Election as a Test of Postwar Liberalism. Gordon Lloyd, p. 750.

\section{Comparative Government and Politics}

Avraham Avi-hai, Ben Gurion, State Builder: Principles and Pragmatism, 1948-1963. Norman L. Zucker, p. 751 .

Elemer Bako, Guide to Hungarian Studies, 2 vols. Arpad Kadarkay, p. 752.

Alan Beals, Village Life in South India. K. Ishwaran, p. 753.

Ivan Berend and György Ránki, Economic Development in East.Central Europe in the 19th and 20th Centuries. Roger E. Kanet, p. 754.

William T. Bluhm, Building an Austrian Nation: The Politrcal Integration of a Western State. Kurt Steiner, p. 755.

Paul R. Brass and Marcus F. Franda, Radical Politics in South Asia. Norman D. Palmer, p. 756.

Manual L. Carlos, Politics and Development in Rural Mexico: A Study of Socio-Economic Modernization. Judith Adler Hellman, p. 758.

Philip M. Chen, Law and Justice: The Legal System in Chma, 2400 B.C.-1960 A.D. L. S. Tao, p. 760.

Michael A. Cohen, Urban Policy and Political Conflict it. Africa: A Study of the Ivory Coast. Richard E. Stren, p. 760.

Emanuel de Kadt and Garith Williams, eds., Sociology and Development. A. Nove. p. 762.

Roger V. Des Forges, Hsi-liang and the Chinese National Revolution. Donald S. Sutton, p. 763.

Lowell Dittmer, Liu Shao-ch'i and the Chinese Cultural Revolution: The Politics of Mass Criticism. Edward Friedman, p. 764.

Louis Dupree, Afghanistan. Leon B. Poullada, p. 766.

Luigi Einaudi, ed., Beyond Cuba: Latin America Takes Charge of Its Future. Abraham F. Lowenthal, p. 766.

Joseph W. Esherick, ed., Lost Chance in China: The World War II Despatches of John S. Service. Susan H. Marsh, p. 768.

Isaiah Frank and Ryokichi Hirono, eds., How the United States and Japan See Each Other's Economy: An Exchange of Views Between the American and Japanese Committees for Economic Development. Lloyd D. Musolf, p. 769 .

John K. Friend, John M. Power, and Chris J. L. Yewlett, Public Planning: The Inter-Corporate Dimension. John Dearlove, p. 770.

Hugh Heclo and Aaron Wildavsky, The Private Government of Public Money. Samuel Brittan, p. 772.

Thomas William Heyck, The Dimensions of British Radicalism: The Case of Ireland, 1874-95. Alan Ward, p. 774.

Yvonne Hirdman, Sverges Kommunistiska Parti 1939-1945. Sten S. Nilson, p. 775.

Roger E. Kanet, ed., Soviet and East European Foreign Policy: A Bibliography of English and Russian Language Publications 1967-1971. Jan F. Triska, p. 775.

Stanley A. Kochanek, Business and Politics in India. Rajni Kothari, p. 776.

D. George Kousoulas, Modern Greece: Profile of a Nation. Nikolaos A. Stavrou, p. 777. 
William M. Lafferty, Industrialization, Community Structure, and Socialism: An Ecological Analysis of Norway, 1875-1924. Penny Gill, p. 778.

Maurice Larkin, Church and State After the Dreyfus Affair: The Separation Issue in France. Jack Hayward, p. 779.

Adrian Leftwich, ed., South Africa: Economic Growth and Political Change, With Comparative Studies of Chile, Sri Lanka and Malaysia. Thomas Karis, p. 780.

Boris Levytsky, comp., The Stalinist Terror in the Thirties: Documentation from the Soviet Press. John Keep, p. 782.

Peter Christian Ludz, Deutschlands Doppelte Zukunft. John Starrels, p. 783.

Gary MacEoin, No Peaceful Way: The Chilean Struggle for Dignity. Edward Glab, Jr., p. 784.

Mervyn Matthews, ed., Soviet Government: A Selection of Official Documents on Internal Policies. Kenneth N. Ciboski, p. 785.

Anatolii N. Melnikov, Sovremennaia klassovaia struktura SShA (The Contemporary Class Structure of the USA). Richard M. Mills, p. 786.

Thomas A. Metzger, The Internal Organization of Ch'ing Bureaucracy: Legal, Normative, and Communica. tion Aspects. Gilbert Rozman, p. 787.

Martin Minogue and Judith Molloy, eds., African Aims and Attitudes: Selected Documents. Raymond F. Hopkins, p. 788.

Fred L. Morrison, Courts and the Political Process in England. John E. Stanga, Jr., p. 789.

Hisahiko Okazaki, A Japanese View of Detente. Katsumi Kobayashi and Hans A. Baerwald, p. 790.

Angelo Panebianco, Le crisi della modernizzazione: L'Esperienza del Brasile e dell'Argentina. Raphael Zariski, p. 791.

William E. Paterson and Ian Campbell, Social Democracy in Post-War Europe. Frank L. Wilson, p. 792.

Howard R. Penniman, ed., Britain at the Polls: The Parliamentary Election of February 1974. Robert C. Frasure, p. 793.

Lord Redcliffe-Maud and Bruce Wood, English Local Government Reformed. Alec Barbrook, p. 794.

Francis Robinson, Separatism Among Indian Muslims: The Politics of the United Provinces' Muslims, 1860-1923. N. Gerald Barrier, p. 795.

Leonard Schroeter, The Last Exodus. Zvi Gitelman, p. 795.

Michèle and Jean Sellier, Guide Politique de Picardie. Aisne. Oise. Somme. Jacques Fomerand, p. 797.

Roger M. Smith, ed., Southeast Asia: Documents of Political Development and Change. Dorothy H. Guyot, p. 797.

K. Rajendra Singh, Politics of the Indian Ocean. Stephen P. Cohen, p. 798.

Frank Stacey, A New Bill of Rights for Britain. Leo Panitch, p. 799.

Philip Stanworth and Anthony Giddens, eds., Elites and Power in British Society. J. D. Lees, p. 800.

Anwar Hussain Syed, China and Pakistan: Diplomacy of an Entente Cordiale. G. Shabbir Cheema, p. 801. David Anson Titus, Palace and Politics in Prewar Japan. Chalmers Johnson, p. 802.

Pierre Elliott Trudeau, ed., The Asbestos Strike. Daniel Jay Baum, p. 803.

Claude E. Welch, Jr. and Arthur K. Smith, Military Role and Rule: Perspectives on Civil-Military Relations. Robert M. Krone, p. 804.

Herbert H. Werlin, Governing an African City: A Study of Nairobi. Peter Marris, p. 805.

Richard W. Wilson, The Moral State: A Study of the Political Socialization of Chinese and American Children. Sheldon Appleton, p. 806.

International Politics, Law and Organization

Gerold Adams, Theory, Law and Policy of Contemporary Japanese Treaties. Hisashi Uchida, p. 808.

Daniel Jay Baum, The Banks of Canada in the Commonwealth Caribbean: Economic Nationalism and Multinational Enterprises of a Medium Power. Maureen Appel Molot, p. 809.

Klaus Billerbeck, Problems and Approaches for Solution of an Association Between Fii/Tonga/Western

Samoa and the European Community. Norman Meller, p. 810.

Lester R. Brown, In the Human Interest. Aaron Lee Segal, p. 811.

J. Alexander Caldwell, American Economic Aid to Thailand. Gavin W. Jones, p. 811 .

Canadian Department of External Affairs, Documents on Canadian External Relations 1909-1941, 7 vols. Roger Frank Swanson, p. 812.

Nazli Choucri, Population Dynamics and International Violence: Propositions, Insights and Evidence. A. F. K. Organski, p. 814.

Jan M. Ciechanowski, The Warsaw Rising of 1944. V. C. Chrypinski, p. 816.

Julio Cotler and Richard R. Fagen, eds., Latin America and the United States: The Changing Political Realities. Kenneth M. Coleman, p. 817.

Alvin J. Cottrell and James D. Theberge, eds., The Western Mediterranean: Its Political, Economic, and Strategic Importance. Harry N. Howard, p. 818.

Moshe Davis, ed., The Yom Kippur War: Israel and the Jewish People. Gary S. Schiff, p. 820.

Robert W. Dean, West German Trade with the East: The Political Dimension. Wolfram F. Hanrieder, $\mathrm{p}$. $8 ? 1$ 
Bruce Dinwiddy, ed., Aid Performance and Development Policies of Western Countries: Studies in U.S., U.K., E.E.C., and Dutch Programs; David Wall, The Charity of Nations: The Political Economy of Foreign Aid. Eugene R. Wittkopf, p. 822.

Yassin El-Ayouty and Hugh C. Brooks, Africa and International Organization. J. Gus Liebenow, p. 824.

Charles Foley and W. I. Scobie, The Struggle for Cyprus. Adamantia Pollis, p. 826.

Martin E. Goldstein, American Policy Toward Laos. Donald Hindley, p. 827.

Leland M. Goodrich, The United Nations in a Changing World. Peter R. Baehr, p. 828.

Keith Griffin, The Political Economy of Agrarian Change. Vernon W. Ruttan, p. 829.

Michael Haas, ed., Basic Documents of Asian Regional Organizations. 4 vols. L. P. Singh, p. 830.

Michael Haas, ed., International Systems: A Behavioral Approach. Urs Luterbacher, p. 831 .

Wolfram F. Hanrieder, ed., The United States and Western Europe: Political, Economic and Strategic Perspectives. Ernest W. Lefever, p. 833.

Shirley Hazzard, Defeat of an Ideal: $A$ Study of the Self-Destruction of the United Nations. Geoffrey Goodwin, p. 834.

Carl Heine, Micronesia at the Crossroads: A Reappraisal of the Micronesian Political Dilemma. L. Patton Davies, p. 834.

Donald L. Herman, The Comintern in Mexico. Roger Hamburg, p. 836.

Richard G. Hewlett and Francis Duncan, eds., Nuclear Navy, 1946-1962. Robert Jervis, p. 836.

Gene T. Hsiao, ed., Sino-American Detente and its Policy Implications. Byron S. J. Weng, p. 838.

George M. Ingram, Expropriation of U.S. Property in South America: Nationalization of Oil and Copper Companies in Peru, Bolivia and Chile. William R. Garner, p. 839.

International Committee for Social Science Information and Documentation, The International Bibliogra* phy of Political Science, Vol. XXI. Frederick Holler, p. 841.

Ghita Ionescu, ed., Between Sovereignty and Integration. R. J. Harrison, p. 841.

Tareq Y. Ismael, The Middle East in World Politics: $A$ Study in Contemporary International Relations. John P. Entelis, p. 843.

Peter N. James, Soviet Conquest from Space. Robert H. Puckett, p. 844.

Lloyd Jensen, Return From the Nuclear Brink: National Interest and the Nuclear Proliferation Treaty. G. R. Lindsey, p. 845 .

Philip G. Jessup, The Birth of Nations. Willard Barber, p. 846.

Geoffrey Kemp, Robert L. Pfaltzgraff, Jr. and Uri Ra'anan, eds., The Superpowers in a Multinuclear World. Herbert Scoville, Jr., p. 847.

Rajni Kothari, Footsteps into the Future: Diagnosis of the Present World and a Design for an Alternative. Werner Levi, p. 848.

Walter Laqueur, Confrontation: The Middle East and World Politics. P. Edward Haley, p. 849.

Howard H. Lentner, Foreign Policy Analysis: A Comparative and Conceptual Approach. Lloyd Jensen, p. 850.

R. M. Logan, Canada, The United States, and the Third Law of the Sea Conference. Ann L. Hollick, p. 851.

Leo A. Loubère, Radicalism in Mediterranean France: Its Rise and Decline, 1848-1914. Eugen Weber, p. 852.

Edward N. Luttwak, The Political Uses of Sea Power. Vincent Davis, p. 853.

Frank U. Merli and Theodore A. Wilson, eds., Makers of American Diplomacy: From Benjamin Franklin to Henry Kissinger. Donald Brandon, p. 854.

Lynn H. Miller and Ronald W. Pruessen, eds., Reflections on the Cold War: A Quarter Century of American Foreign Policy. Robert James Maddox, p. 855.

John Norton Moore, ed., Law and Civil War in the Modern World. Yoram Dinstein, p. 856.

Dana G. Munro, The United States and the Caribbean Republics, 1921-1933. Jerome Slater, p. 858.

Chris N. Okeke, Controversial Subjects of Contemporary International Law: An Examination of the New Entities of International Law and Their Treaty-Making Capacity. Henry G. Schermers, p. 859.

J. Roland Pennock and John W. Chapman, eds., The Limits of Law. J. W. Harris, p. 859.

John Quigley, The Soviet Foreign Trade Monopoly: Institutions and Laws. Robert W. Clawson, p. 861 .

Ruth B. Russell et al., Air, Water, Earth, Fire: The Impacts of the Military on World Environmental Order. Harold Sprout, p. 862.

Robert A. Scalapino, Asia and the Road Ahead: Issues for the Major Powers. Richard L. Park, p. 862.

Wayne A. Selcher, The Afro-Asian Dimension of Brazilian Foreign Policy, 1956-1972. K. Larry Storrs, p. 864.

Dale R. Tahtinen, The Arab-Israeli Military Balance Since October 1973. Marvin C. Feuerwerger, p. 865.

Ronald Tiersky, French Communism: 1920-1972. W. W. Kulski, p. 865.

Francis O. Wilcox, ed., China and the Great Powers: Relations with the United States, the Soviet Union, and Japan. William R. Feeney, p. 867.

George Woodcock, Who Killed the British Empire?: An Inquest. Kenneth E. Miller, p. 868.

Abraham Yeselson and Anthony Gaglione, $A$ Dangerous Place: The United Nations as a Weapon in International Politics. Edward H. Buehrig, p. 869. 


\section{LO SPETTATORE INTERNAZIONALE}

A quarterly review of international politics published in English by the Istituto Affari Internazionali (IAI) of Rome. Each issue contains articles by Italian and foreign authors and a regular survey of Italy's position in international politics and commerce.

Among the articles published in recent issues were the following: Stefano Silvestri-Security, the Atlantic Alliance and the Italian Question Joseph Sassoon - Trends of Competitiveness and Industrial Policy of Japan in Southeast Asia

Richard Walker - Italy and Europe: The Political Parties, 1968-75

Gianni Bonvicini and Marinella Neri-New Political and Institutional Balances within the European Common Market

Giampaolo Calchi-Novati and Francesco Cocco-Italian Political Forces and the International Scene

In forthcoming issues of 1977 articles on European foreign policy, the EEC's Mediterranean policy, the manageability of European economies, the Communist parties in Southern Europe, and Italy's place in the international scene will be featured.

Editor-in-chief: Cesare Merlini

Editorial Offices: Istituto affari internazionali Viale Mazzini 88 (Rome) 00195

Subscription rates for 1977 :

Italy

Europe

Other Countries
Lit. 5000

Lit. 6000 or $\$ 9.50$

Lit. 7000 or $\$ 11.00$

Orders should be sent directly to the publisher:

Società editrice il Mulino

Via S. Stefano 6-P.O. Box 119

40100 (Bologna) Italy 


\title{
The American Political Science Association
}

\author{
1527 New Hampshire Avenue, N.W., Washington, D.C. 20036
}

President: SAMUEL H. BEER, Harvard University; President-Elect: JOHN C. WAHLKE, University of Iowa; Vice Presidents: PHILIP E. CONVERSE, University of Michigan; MATTHEW HOLDEN, JR., Public Service Commission, State of Wisconsin; FRANK J. SORAUF, University of Minnesota; Secretary: FRED I. GREENSTEIN, Princeton University; Treasurer: DINA A. ZINNES, Indiana University; Program Co-Chairmen: HAR VEY C. MANSFIELD, JR., Harvard University; JAM ES Q. WILSON, Harvard University; Executive Director: EVRON KIR KPATRICK, 1527 New Hampshire Avenue, N.W., Washington, D.C. 20036; Managing Editor, APSR: NELSON W. POLSBY, University of California, Berkeley.

COUNCIL: (Above-named Officers ex officiis), 1976-1978: JAMES DAVID BARBER, Duke University; SUZANNE BERGER, Massachusetts Institute of Technology; JAMES B. CHRISTOPH, Indiana University; DANIEL J. ELAZAR, Temple University; HERBERT JACOB, Northwestern University; M. KENT JENNINGS, University of Michigan; INEZ SMITH REID, Barnard College; JAMES N. ROSENAU, University of Southern California; 1977-79: MARGUERITE ROSS BARNETT, Howard University; ROBERT T. HOLT, University of Minnesota; MARTIN LANDAU, University of California, Berkeley; DAVID R. MAYHEW, Yale University; ROBERT D. PUTNAM, University of Michigan; CLEMENT E. VOSE, Wesleyan University; JAMES Q. WILSON, Harvard University; BETTY H. ZISK, Boston University.

FORMER PRESIDENTS: FRANK J. GOODNOW, ALBERT SHAW, FREDERIC N. JUDSON, JAMES BRYCE, A. LAWRENCE LOWELL, WOOD ROW WILSON, SIMEON E. BALDWIN, ALBERT BUSHNELL HART, W. W. WILLOUGHBY, JOHN BASSETT MOORE, ERNST FREUND, JESSE MACY, MUNROE SMITH, HENRY JONES FORD, PAUL S. REINSCH, LEO S. ROWE, WILLIAM A. DUNNING, HARRY A. GAR FIELD, JAMES W. GARNER, CHARLES E. MERRIAM, CHA RLES A. BEARD, WILLIAM B. MUNRO, JESSE S. REEVES, JOHN A. FAIRLIE, BENJAMIN F. SHAMBAUGH, EDWARD S. CORWIN, WILLIAM F. WILLOUGHBY, ISIDOR LOEB, WALTER J. SHEPARD, FRANCIS W. COKER, ARTHUR N. HOLCOMBE, THOMAS REED POWELL, CLARENCE A. DYKSTRA, CHA RLES GROVE HAINES, ROBERT C. BROOKS, FREDERIC A. OGG, WILLIAM ANDERSON, ROBERT E. CUSHMAN, LEONARD D. WHITE, JOHN M. GAUS, WALTER F. DODD, ARTHUR W. MACMAHON, HENRY R. SPENCER, QUINCY WRIGHT, JAMES K. POllock, Peter H. Odegard, LUTHER H. GUlick, PENDleton HeRRING, RALPH J. BUNCHE, CHARLES MCKINLEY, HAROLD D. LASSWELL, E. E. SCHATTSCHNEIDER, V. O. KEY, JR., R. TAYLOR COLE, CARL B. SWISHER, EMMETTE S. REDFORD, CHARLES S. HYNEMAN, CARL J. FRIEDRICH, C. HERMAN PRITCHETT, DAVID B. TRUMAN, GABRIEL A. ALMOND, ROBERT A. DAHL, MERLE FAINSOD, DAVID EASTON, KARL W. DEUTSCH, ROBERT E. LANE, HEINZ EULAU, ROBERT E. WARD, AVERY LEISERSON, AUSTIN RANNEY, JAMES MACGREGOR BURNS.

\section{The American Political Science Review}

Department of Political Science, University of California, Berkeley 94720

EDITORIAL BOARD: NELSON W. POLSBY, Managing Editor, University of California, Berkeley CHAR LES O. JONES, Managing Editor Elect, University of Pittsburgh; PHILIP SIEGELMAN, Book Review Editor, San Francisco State University; SHLOMO AVINERI, The Hebrew University of Jerusalem; LUCIUS BARKER, Washington University; BRLAN BARRY, University of British Columbia; RICHARD A. BRODY, Stanford University; SAMUEL D. COOK, Dillard University; ELMER E. CORNWELL, Brown University; S. RUFUS DAVIS, Monash University; ROBERT J. JACKSON, Carleton University; ROBERT JERVIS, University of California, Los Angeles; DALE ROGERS MARSHALL, University of California, Davis; RUSSELL D. MURPHY, Wesleyan University; JOAN M. NELSON, Washington, D.C.; J. ROLAND PENNOCK, Swarthmore College; SAMUEL L. POPKIN, University of California, San Diego; ROBERT D. PUTNAM, University of Michigan; DOUGLAS W. RAE, Yale University; AUSTIN RANNEY, American Enterprise Institute; GIOV ANNI SARTORI, University of Florence; MICHAEL J. SHAPIRO, University of Hawail; JAY STARLING, Southern Methodist University; STEPHEN V. STEPHENS, Baltimore, Maryland; GEORGE E. VON DER MUHLL, University of California, Santa Cruz; RICHARD A. WATSON, University of Missouri; RICHARD WINTERS, Dartmouth College. MANUSCRIPT EDITOR: ELLEN Y. SIEGELMAN. EDITORIAL ASSISTANT: BETSEY COBB. EDITORIAL INTERNS: ROBERT ARSENEAU, JONATHAN BENDOR, BETH CAPELL, DON CHISHOLM, DAVID FLANDERS, STEPHEN GENCO, EVELYN DEBORAH JAY, JOHN Q. JOHNSON, PAUL D. KARPS, JAMES I. LENGLE, DAVID B. MAGLEBY, DAVID RICHMAN, JENNY RING, STEVEN ROSENSTONE, STUART A. ROSS, SERGE TAYLOR, PHILIP J. WILSON, JOHN ZALLER. 
The American Political Science Review, published quarterly during the months of March, June, September, and December, is supplied to all APSA members. Membership dues are charged according to the following schedule:

$\begin{array}{lc}\begin{array}{l}\text { Membership Category } \\ \text { Regular } \\ \text { Annual Income }\end{array} & \text { Dues } \\ \text { Under } \$ 12,000 & \\ \$ 12,000-14,999 & \$ 25 \\ \$ 15,000-19,999 & \$ 30 \\ \$ 20,000-24,999 & \$ 35 \\ \$ 25,000-29,999 & \$ 40 \\ \$ 30,000 \text { and over } & \$ 45 \\ \text { Student and Retired } & \$ 50 \\ \text { Family } & \$ 12 \\ \text { Life } & \$ 5 \\ \text { Institutional (includes } A P S R \text { and } P S \text { ) } & \$ 1000 \\ & \$ 50 \text { domestic }\end{array}$

Student memberships are limited to five years per person. Foreign currency at the official exchange rate will be accepted for foreign subscriptions and foreign membership fees. The equivalent of $\$ 3$ for additional postage should be added for foreign subscriptions.

Current issues are priced at $\$ 10.50$ per copy; for back issues prior to 1970 address Walter J. Johnson, Inc., 355 Chestnut St., Norwood, New Jersey 07648; for issues 1970 and later send request directly to the American Political Science Association.

Applications for membership, orders for the Review, and remittances should be addressed to the Executive Director, The American Political Science Association, 1527 New Hampshire Ave., N.W., Washington, D.C. 20036. Notices of change of address should be received in the Washington office by the 25 th day of the months before publication.

\section{INSTRUCTIONS TO CONTRIBUTORS}

Address correspondence about contributions to the Review concerning issues before the issue of September 1977 to Nelson W. Polsby, Department of Political Science, University of California, Berkeley, California 94720; and issues after September 1977 (including all new manuscripts) starting January 1, 1976, to Charles O. Jones, American Political Science Review, Department of Political Science, University of Pittsburgh, Pittsburgh, Pennsylvania 15260. Address all correspondence about pending manuscripts to Charles O. Jones.

Please submit four copies of a manuscript to be considered for publication. Unfortunately, due to increased postage costs, we can no longer return manuscripts to the author. Manuscripts must be typed and mimeographed or photocopied, and with all written material double-spaced (including quotations). Please do not send the original typescript. Since manuscripts are sent out anonymously for evaluation, the author's name and affiliation should appear only on a separate covering sheet and all footnotes identifying the author should also appear on a separate sheet. An abstract of less than 150 words should accompany the manuscript.

The footnote form is that used by most scientific journals. Explanatory notes only will be permitted for most manuscripts (see below); references will be listed alphabetically at the end of the manuscript; and in-text references will be made by inserting author or title, year, and page number, if appropriate. For illustration see Fred I. Greenstein and Nelson W. Polsby, eds., Handbook of Political Science (Reading, Mass.: Addison-Wesley, 1975). Note: Authors of manuscripts on the history of political thought may, if they prefer, use the traditional footnote form when referring to the individual theorist's work; the reference form should be used when referring to secondary works.

All manuscripts will be examined carefully for length. Referees will be asked to recommend where cuts might be made, without affecting the principal contribution. Manuscripts over 30 pages will be reviewed with particular care to determine if such length is warranted. Except in extraordinary circumstances, manuscripts over 50 pages will be returned to the author. Resubmission may follow compliance with the page limit. Manuscripts must be prepared as noted above, double-spaced throughout, with standard margins. Tables, charts, and references will be included in the page count.

Communications must follow the form of regular manuscripts (including reference listings where appropriate). They must be brief and to the point.

Figures should be drawn on white paper with India ink and the original tracings or drawings retained by the author (for transmission later to the printer). Copies only should accompany the manuscript. Tables should be typed on a separate page. Insert a guide line, e.g., "Table 1 about here," at the appropriate place in the manuscript.

Address books intended for review to Paul A. Beck, Book Review Editor, American Political Science Review, Department of Political Science, Mervis Hall, University of Pittsburgh, Pittsburgh, Pennsylvania 15260. Information, including News and Notes, for the Association's news-journal, $P S$, should be sent to 1527 New Hampshire Ávenue, N.W., Washington, D.C. 20036; advertising reprint and circulation correspondence should be sent to the Executive Director at the Washington office. Domestic claims for non-receipt of issues must be made within six months of the month of publication; overseas claims, one year. Advertising information and rates are available from Nancy Ranney, Adv. Manager, APSA, 1527 New Hampshire Avenue, N.W., Washington, D.C. 20036.

Articles and notes appearing in the Review before the June 1953 issues were indexed in The Reader's Guide to Periodical Literature. Current issues are indexed by The International Political Science Abstracts and the Social Sciences and Humanities Index. Microfilm of the Review, beginning with Volume 1 , may be obtained from University Microfilms, 313 North First Street, Ann Arbor, Michigan 48106. A Cumulative Index of the Review, Volumes 1-62; 1906-1968, may also be obtained from University Microfilms. Articles appearing in the Review are listed regularly in $A B C$ Pol Sci and Current Contents: Behavioral, Social \& Management Sciences. Book reviews are indexed in Book Review Index. 